Rev. Inst. Flor. v. 26 n. 2 p. 193-201 dez. 2014

http://dx.doi.org/10.4322/rif.2014.015

ISSN impresso 0103-2674/on-line 2178-5031

\title{
RADIAL VARIATION OF WOOD ANATOMY AND BASIC DENSITY OF Anadenanthera colubrina (Vell.) Brenan. ${ }^{1}$
}

\author{
VARIAÇÃO RADIAL DA ANATOMIA E DENSIDADE BÁSICA DA MADEIRA DE \\ Anadenanthera colubrina (Vell.) Brenan.
}

\author{
Eduardo Luiz LONGUI ${ }^{2 ;}$; Israel Luiz de LIMA²; Osny Tadeu de AGUIAR; \\ Sandra Monteiro Borges FLORSHEIM²; Itiberê Moura Sckerratt SUCKOW ${ }^{2}$
}

\begin{abstract}
We investigated wood samples of five Anadenanthera colubrina trees, aiming to study radial variation of anatomy and basic density. The trees were cut from "lote 5 do Rodoanel trecho sul" in Embu municipality, State of São Paulo, where vegetation is classified as Montane Ombrophilous Dense Forest and climate is classified as Cwa. We cut discs from the diameter at breast height - $\mathrm{DBH}$, and then cut samples from pith-to-bark to anatomical and basic density analysis. The results suggest that Anadenanthera colubrina has a very common anatomical and basic density radial variation pattern from pith-to-bark between hardwoods with an increase in vessel diameter favoring hydraulic conductivity, fiber wall thickness and length, ray height and width, and basic density. While the negative relationship between vessel diameter and frequency is well reported for many species, it has not been observed in A. colubrina because vessel frequency oscillates radially. This typical radial pattern also occurs in other native species in planting conditions, already demonstrated by our group in other studies, obviously with some changes depending on species.
\end{abstract}

Keywords: pith-bark variation; hydraulic conductivity; angico branco; Brazilian native wood.

RESUMO - Investigamos amostras de madeira de cinco árvores de Anadenanthera colubrina objetivando estudar a variação radial da anatomia e densidade básica. As árvores foram cortadas no lote 5 do Rodoanel trecho sul, no município de Embu, com a vegetação de Floresta Ombrófila Densa Montana e clima do tipo Cwa. Cortamos discos à altura do peito - DAP e destes obtivemos amostras radiais da medula para a casca, destas preparamos amostras para a determinação anatômica e da densidade básica. Os resultados sugerem que Anadenanthera colubrina apresenta um padrão radial de variação bastante comum no sentido medula-casca para as angiospermas arbóreas, com aumento no diâmetro dos vasos, consequentemente condutividade hidráulica, comprimento e espessura da parede da fibra, altura e largura do raio e densidade básica. Contudo, a relação negativa entre diâmetro $\mathrm{e}$ frequência dos vasos é bem reportada para muitas espécies, mas não ocorreu em A. colubrina, pois a frequência oscilou radialmente. Esse típico padrão radial também ocorre em outras espécies nativas em condições de plantio, como já demostrado por nosso grupo em outros estudos, obviamente com algumas alterações dependendo da espécie.

Palavras-chave: variação medula-casca; condutividade hidráulica; angico branco; madeira nativa do Brasil. 


\section{INTRODUCTION}

Anadenanthera colubrina (Vell.) Brenan (Fabaceae-Mimosoideae), locally known as "angico-branco, angico liso, cambuí, monjoleiro", is a native species, not endemic to Brazil, with geographical distribution in the Northeast (Bahia, Ceará, Paraíba, Pernambuco, Piauí, Rio Grande do Norte, and Sergipe States), Midwest (Distrito Federal, Goiás, Mato Grosso do Sul, and Mato Grosso States), Southeast (Minas Gerais, Rio de Janeiro, and São Paulo States), and the South (Paraná State), with vegetation types that include Caatinga, Cerrado, Floresta Estacional Semidecidual (Seasonal Semideciduous Forest), and Floresta Ombrófila (Rain Forest) (Morim, 2014). This pioneer deciduous heliophytic species shows characteristics common to secondary forest regions above $400 \mathrm{~m}$ in elevation, reaching 12-15 $\mathrm{m}$ in height and trunk diameter of $30-50 \mathrm{~cm}$. Depending on environmental conditions, A. colubrina trees can reach up to $35 \mathrm{~m}$ in height and $100 \mathrm{~cm}$ diameter at breast height (Lorenzi, 2002).

Silvicultural characteristics of this species include irregular growth with bifurcations that may occur from the base. After cutting and pruning, sprouting shows good results, both in pure plantings in full sunlight and in mixed plantings (Carvalho, 1994). Characterized by sapwood and heartwood that is brown with golden shades, A. colubrina provides beautiful decorative effects and medium texture with interlocked, irregular grain that splits easily, but is, nonetheless, durable. A. colubrina has several uses, including woodworking, packaging and, shipbuilding, as well as being one of the Caatinga species most used as coal (Johnson, 1985; Carvalho, 1994). In addition, the bark is used to treat respiratory disorders (Peters, 2011). A. colubrina has been used for multiple purposes within the rural communities of northeastern Brazil, is largely used in rural constructions, as an energy source, as well as in popular medicines. Local management of this species is based on simple maintenance and harvesting of individuals in agroforest home gardens (Monteiro et al., 2006; Albuquerque and Andrade, 2002a; Albuquerque and Andrade, 2002b).
Lachenbruch et al. (2011) describe the complexity and interactions in the development of woody plants that may cause the typical radial pattern, and the authors mention that gradual radial variations are the rule in many properties of wood, including differences in mature wood when compared with juvenile wood - in general, the latter presents shorter cells with smaller diameters and thinner cell walls.

We summarize the results of radial variation for some anatomical features of vessels, fibers, rays and wood density in eight other Brazilian native species that we studied previously to give a sense of how the radial variation occurs. We noticed that vessel diameter increased toward the bark in all eight species: Plathymenia reticulata (Longui et al., 2012), Astronium graveolens (Santos et al., 2011), Balfourodendron riedelianum (Lima et al., 2011a), Cariniana legalis (Lima et al., 2011b), Gallesia integrifolia (Longui et al., 2011), Piptadenia gonoacantha (Longui et al., 2010), Croton floribundus (Lima et al., 2010) and Luehea divaricata (Longui et al., 2009). While vessel frequency increased in Balfourodendron riedelianum (Lima et al., 2011a), it decreased in other four species: Plathymenia reticulata (Longui et al., 2012), Astronium graveolens (Santos et al., 2011), Cariniana legalis (Lima et al., 2011b) and Gallesia integrifolia (Longui et al., 2011).

Fiber length increased in four species: Plathymenia reticulata (Longui et al., 2012), Astronium graveolens (Santos et al., 2011), Gallesia integrifolia (Longui et al., 2011), and Cariniana legalis (Lima et al., 2011b). Fiber wall thickness increased in six species: Astronium graveolens (Santos et al., 2011), Balfourodendron riedelianum (Lima et al., 2011a), Cariniana legalis (Lima et al., 2011b), Gallesia integrifolia (Longui et al., 2011), Piptadenia gonoacantha (Longui et al., 2010) and Luehea divaricata (Longui et al., 2009). Wood density increased in three species: Astronium graveolens (Santos et al., 2011), Balfourodendron riedelianum (Lima et al., 2011a) and Luehea divaricata (Longui et al., 2009).

Ray height increased in four species: Balfourodendron riedelianum (Lima et al., 2011a), Cariniana legalis (Lima et al., 2011b), Gallesia integrifolia (Longui et al., 2011) and Piptadenia gonoacantha (Longui et al., 2010). 
Ray width decreased in Balfourodendron riedelianum (Lima et al., 2011a) and increased in three species: Plathymenia reticulata (Longui et al., 2012), Gallesia integrifolia (Longui et al., 2011), and Piptadenia gonoacantha (Longui et al., 2010). Ray frequency decreased in three species: Balfourodendron riedelianum (Lima et al., 2011a), Piptadenia gonoacantha (Longui et al., 2010), and Croton floribundus (Lima et al., 2010).

Studies that evaluate the radial and axial variation in the trunk have illustrated how the architecture adopted by different species can safely and efficiently transport water (Fan et al., 2009). However, radial and axial variation in trunk can also be a characteristic used to distinguish plants that have commercial importance, making it possible to establish the most suitable raw material for a given application. The investigation of the radial variation in natural conditions also helps improve the understanding of anatomical differences and wood properties found on plantations (Bosman et al., 1994) where different spacing is employed, in contrast to trees growing in the natural forest.

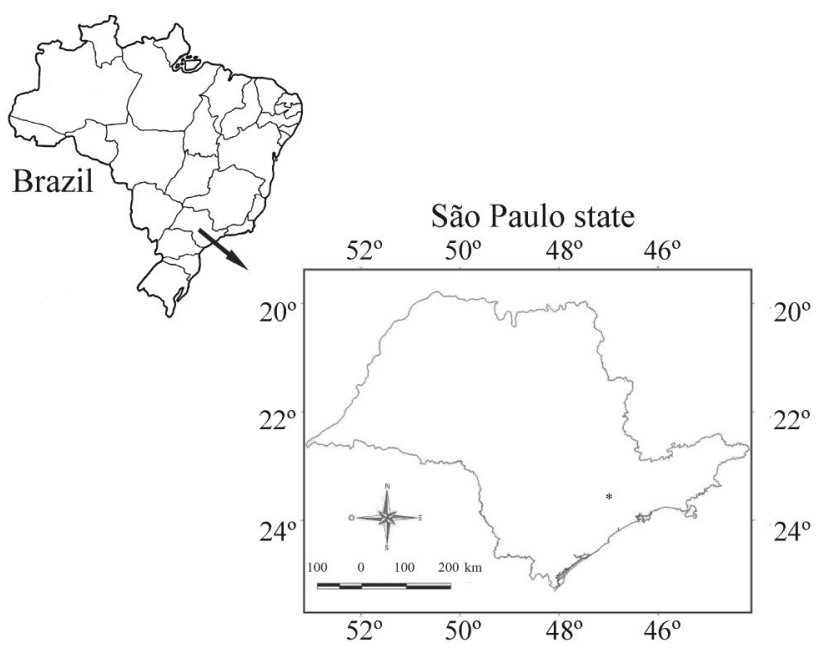

The aim of this study was to investigate the radial variation of wood anatomy and basic density of Anadenanthera colubrina (Vell.) Brenan trees growing under natural conditions.

\section{MATERIAL AND METHODS}

\subsection{Study Site and Sampling}

Wood samples were collected in Embu municipality, State of São Paulo, between the Regis Bittencourt and Imigrantes Highways. Samples were taken from vegetation removed for construction of the Rodoanel Highway. The geographic coordinates of the collection area are 2341'50.6”'S and 46 49'06.4" W (Figure 1). Embu vegetation is classified as Montane Ombrophilous Dense Forest (Franco et al., 2007). According to the Centro de Pesquisas Meteorológicas e Climáticas Aplicadas à Agricultura - CEPAGRI (Centre for Meteorological and Climate Research Applied to Agriculture) (2014), the climate of Embu is Cwa (humid subtropical climate).

Figure 1. Location of Embu municipality $(*)$ in São Paulo State, Brazil, and mean monthly precipitation and temperature. Data from 1961-1990 (CEPAGRI, 2014).

Figura 1. Localização do município de Embu (*) em São Paulo, Brasil, e as médias mensais de precipitação e temperatura. Dados entre 1961-1990 (CEPAGRI, 2014). 
Five trees of Anadenanthera colubrina were identified in the field. These trees were cut, and discs were removed at breast height diameter (DBH, $1.30 \mathrm{~m}$ in height). Discs averaged $30 \mathrm{~cm}$ in diameter. From each disc, a strip with $6 \mathrm{~cm}$ deep was cut, and seven samples from pith-to-bark, independent of $\mathrm{DBH}$ variation, seven samples were obtained on all discs, consequently with different dimensions. From the top part, we investigated wood anatomical features, and from the bottom samples, we determined basic density values (Figure 2).

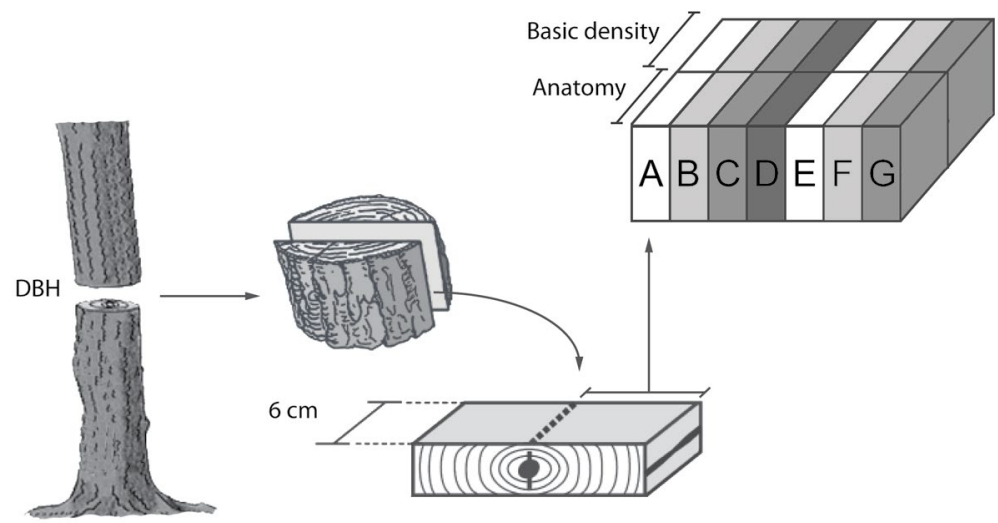

Figure 2. Schematic illustration of wood samples for anatomic measurements and basic density determination.

Figura 2. Representação esquemática da amostragem para anatomia e densidade básica.

\subsection{Anatomical and Basic Density Analysis}

Small pieces were cut from the side of samples, and macerations were prepared according to the modified Franklin method (Berlyn and Miksche, 1976), modification is due to differences in the concentration of hydrogen peroxide in solution that is higher in our study. Then, samples were boiled for about $60 \mathrm{~min}$ in water, glycerin and alcohol (4:1:1), and $16 \mu \mathrm{m}$ transverse and tangential longitudinal sections were cut with a sledge microtome. Sections were stained with a $1 \%$ solution of safranin, washed with distilled water, and mounted in a solution of water and glycerin (1:1) on slides. The terminology followed the IAWA list of Microscopic Features for Hardwood Identification (IAWA Committee, 1989). All anatomical measurements were obtained using an Olympus CX 31 microscope equipped with a digital camera (Olympus Evolt E330) and a computer with image analyzer software (Image-Pro 6.3).

Hydraulic conductivity was calculated based on vessel diameter, using the following equation: $\mathrm{Kh}=\pi \mathrm{D} 4 / 128 \eta$, where $\mathrm{D}$ is the diameter, $\eta$ is the viscosity index of water $\left(1.002 \times 10^{-9} \mathrm{MPa} \mathrm{s}\right.$ at $20^{\circ} \mathrm{C}$ ), and $\mathrm{Kh}$ is the hydraulic conductivity (Scholz et al., 2013).
Samples $2 \times 2 \times 3 \mathrm{~cm}$ were saturated in water by treatment with a vacuum system for $72 \mathrm{~h}$ to obtain the green volume of wood. The samples were dried $\left(105 \pm 3{ }^{\circ} \mathrm{C}\right)$ in a laboratory kiln for three days to determine the oven-dry mass for calculate basic density (Glass and Zelinka, 2010).

\subsection{Statistical Analysis}

We performed a parametric analysis of variance (One-Way Analysis of Variance). When a normal distribution of data was not observed, data were transformed (i.e., square root). In the case of a significant difference, Tukey's test was applied to identify pairwise determinants of differences. Only results with $\mathrm{p}<0.01$ were considered significant.

\section{RESULTS}

In a general, vessel diameter (Figure 3), hydraulic conductivity, fiber length and wall thickness (Figure 4), rays height and width and basic density increased from pith-to-bark (Table 1). Vessel frequency oscillated radially (Table 1). However, ray frequency decreased towards the bark (Table 1). 

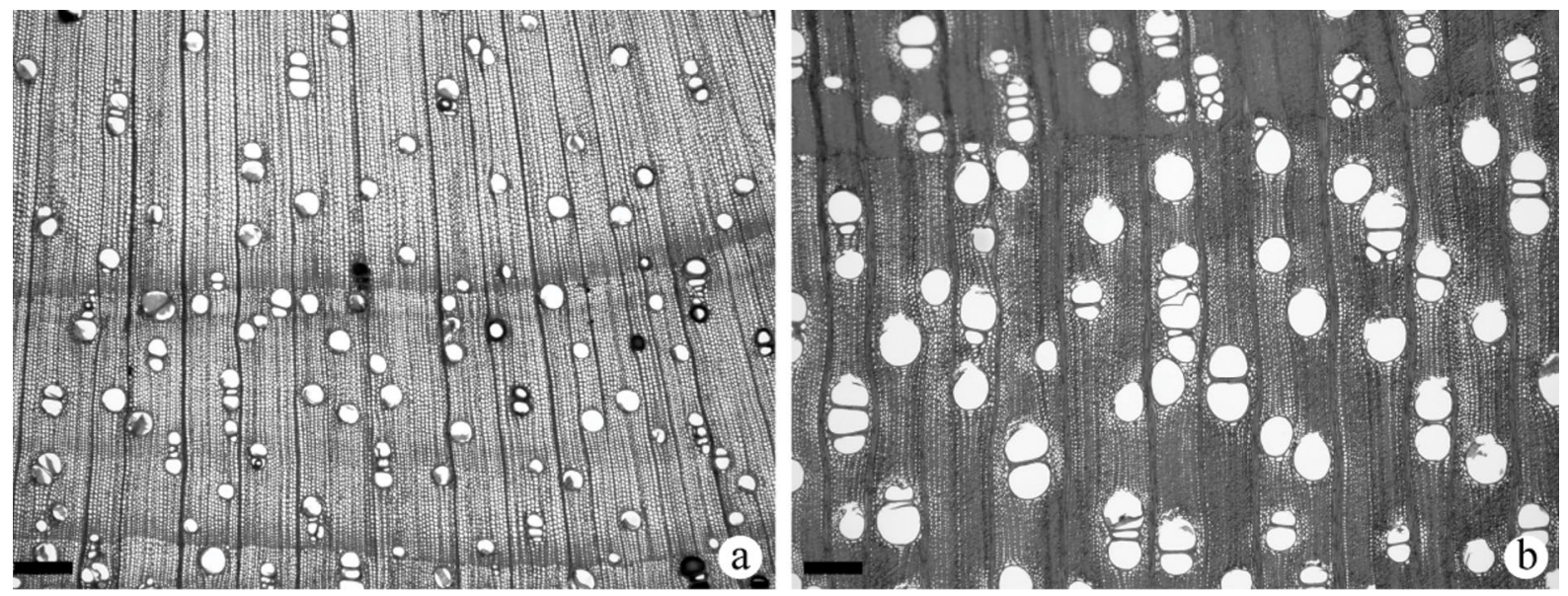

Figure 3. Transverse sections of Anadenanthera colubrina wood. Pith position (a). Bark position (b). Scale bars $=200 \mu \mathrm{m}$.

Figura 3. Secções transversais da madeira de Anadenanthera colubrina. Posição próxima da medula (a). Posição próxima da casca (b). Barra de escala $=200 \mu \mathrm{m}$.

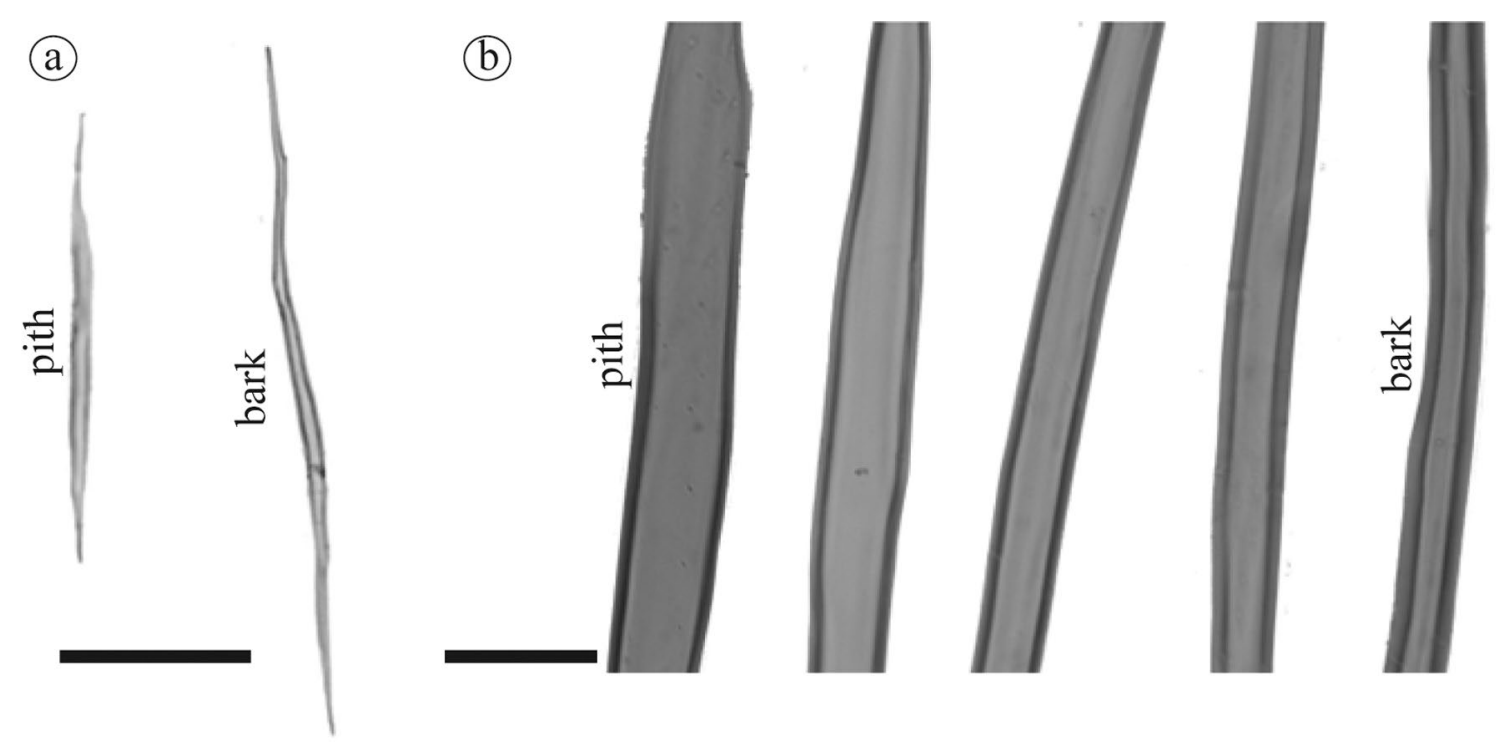

Figure 4. Difference in length (a) and fiber wall thickness (b) of Anadenanthera colubrina wood between pith and bark. We emphasize that only five radial positions are represented, as the visual difference between the fibers in some positions was very small. Scale bar in $\mathrm{a}=250 \mu \mathrm{m}$, in $\mathrm{b}=50 \mu \mathrm{m}$.

Figura 4. Diferença no comprimento (a) e na espessura da parede das fibras (b) da madeira de Anadenanthera colubrina entre medula e casca. Ressaltamos que apenas cinco posições radiais estão representadas, uma vez que a diferença visual entre as fibras em algumas posições foi muito pequena. Barra de escala em a $=250 \mu \mathrm{m}$ e em $\mathrm{b}=50 \mu \mathrm{m}$. 
Table 1. Wood feature variations of Anadenanthera colubrina from pith-to-bark.

Tabela 1. Variação das características anatômicas de Anadenanthera colubrina no sentido medula-casca.

\begin{tabular}{ccccccccccc}
\hline \multicolumn{10}{c}{ Wood Features } \\
\hline & VEL & VD & VF & Kh & FL & FWT & RH & RW & RF & BD \\
\hline A (pith) & $486 \mathrm{~b}$ & $92 \mathrm{~d}$ & $12.1 \mathrm{a}$ & $2.495 \mathrm{~d}$ & $663 \mathrm{f}$ & $3.6 \mathrm{c}$ & $300 \mathrm{c}$ & $39 \mathrm{bc}$ & $5.9 \mathrm{a}$ & $0.35 \mathrm{~b}$ \\
B & $496 \mathrm{~b}$ & $119 \mathrm{c}$ & $11.1 \mathrm{ab}$ & $6.628 \mathrm{c}$ & $724 \mathrm{e}$ & $3.9 \mathrm{~b}$ & $256 \mathrm{~d}$ & $33 \mathrm{c}$ & $5.4 \mathrm{~b}$ & $0.36 \mathrm{~b}$ \\
C & $517 \mathrm{ab}$ & $127 \mathrm{c}$ & $8.8 \mathrm{c}$ & $8.662 \mathrm{c}$ & $836 \mathrm{~d}$ & $3.8 \mathrm{~b}$ & $296 \mathrm{~cd}$ & $35 \mathrm{c}$ & $5.1 \mathrm{bc}$ & $0.39 \mathrm{~b}$ \\
D & $535 \mathrm{a}$ & $128 \mathrm{bc}$ & $8.6 \mathrm{c}$ & $8.223 \mathrm{c}$ & $902 \mathrm{c}$ & $4.2 \mathrm{ab}$ & $308 \mathrm{c}$ & $40 \mathrm{~b}$ & $4.9 \mathrm{~cd}$ & $0.46 \mathrm{ab}$ \\
E & $541 \mathrm{a}$ & $138 \mathrm{ab}$ & $8.7 \mathrm{c}$ & $12.323 \mathrm{~b}$ & $954 \mathrm{~b}$ & $4.2 \mathrm{a}$ & $312 \mathrm{bc}$ & $40 \mathrm{~b}$ & $4.9 \mathrm{~cd}$ & $0.50 \mathrm{ab}$ \\
F & $545 \mathrm{a}$ & $150 \mathrm{a}$ & $9.9 \mathrm{bc}$ & $17.152 \mathrm{a}$ & $1018 \mathrm{a}$ & $4.4 \mathrm{a}$ & $372 \mathrm{a}$ & $48 \mathrm{a}$ & $4.8 \mathrm{~cd}$ & $0.52 \mathrm{a}$ \\
G (bark) & $521 \mathrm{ab}$ & $140 \mathrm{a}$ & $10.2 \mathrm{~b}$ & $13.817 \mathrm{ab}$ & $1054 \mathrm{a}$ & $4.0 \mathrm{~b}$ & $352 \mathrm{ab}$ & $46 \mathrm{a}$ & $4.6 \mathrm{~d}$ & $0.54 \mathrm{a}$ \\
\hline
\end{tabular}

$\mathrm{VEL}=$ Vessel element length $(\mu \mathrm{m}), \mathrm{VD}=$ Vessel diameter $(\mu \mathrm{m}), \mathrm{VF}=$ Vessel frequency $\left(\mathrm{n}^{\mathrm{o}} \mathrm{mm}^{-2}\right), \mathrm{Kh}=$ Hydraulic conductivity $\left(\mathrm{m}^{4} / \mathrm{MPa}^{-1} * \mathrm{~s}^{-1}\right), \mathrm{FL}=$ Fiber length $(\mu \mathrm{m}), \mathrm{FWT}=$ Fiber wall thickness $(\mu \mathrm{m}), \mathrm{RH}=$ Ray height $(\mu \mathrm{m})$, $\mathrm{RW}=$ Ray width $(\mu \mathrm{m}), \mathrm{RF}=$ Ray frequency $\left(\mathrm{n}^{\mathrm{o}} \mathrm{mm}^{-1}\right), \mathrm{BD}=$ Basic density $\left(\mathrm{g} \mathrm{cm}^{-3}\right)$. Different letters in the same column indicate statistical significance by the Tukey's test ( $\mathrm{p}$ value $<0.01$ ).

$\mathrm{VEL}=$ Comprimento do elemento de vaso $(\mu \mathrm{m}), \mathrm{VD}=$ Diâmetro de vaso $(\mu \mathrm{m}), \mathrm{VF}=$ Frequência de vaso $\left(\mathrm{n}^{\mathrm{o}} \mathrm{mm}^{-2}\right)$, $\mathrm{Kh}=$ Condutividade hidráulica $\left(\mathrm{m}^{4} / \mathrm{MPa}^{-1} * \mathrm{~s}^{-1}\right), \mathrm{FL}=$ Comprimento da fibra $(\mu \mathrm{m}), \mathrm{FWT}=$ Espessura da parede da fibra $(\mu \mathrm{m}), \mathrm{RH}=$ Altura do raio $(\mu \mathrm{m}), \mathrm{RW}=$ Largura do raio $(\mu \mathrm{m}), \mathrm{RF}=$ Frequência do raio $\left(\mathrm{n}^{\mathrm{o}} \mathrm{mm}^{-1}\right), \mathrm{BD}=$ Densidade básica $\left(\mathrm{g} \mathrm{cm}^{-3}\right)$. Letras diferentes na mesma coluna indicam variação estatística significativa pelo teste de Tukey (valor de $\mathrm{p}<0,01$ ).

\section{DISCUSSION}

Many authors mention that gradual radial variations are the rule in many properties of wood (Lachenbruch et al., 2011). However, these variations should be studied and understood in each species. For example, in another study we collected samples of Alchornea sidifolia in the same area and period of year as indicated in the present study, and we found few variations in the pith-to-bark direction with increases only in fiber length, vessel diameter and intervessel pit diameter (Santini Júnior et al., 2010). However, in $A$. colubrina, variations occurred in all studied features with increases or decreases from pith-to-bark. Studying Anadenanthera peregrina, Teixeira (2008) also observed an increase in fiber length and fiber wall thickness, as well as basic density from pith to bark. This author carried out the tree sampling (average DBH of $44.2 \mathrm{~cm}$ ) in native forest at the Universidade Federal de Viçosa, Minas Gerais State, with Cwb (subtropical highland variety) climate type.

Although radial variation is shared among tree species, these results show species that are more homogeneous than others, and although small variations can occur, they are not statistically significant. In this discussion, it should be noted that such changes may be either ontogenetically fixed or plastic, and, as such, we need to investigate whether such changes are triggered by factors that vary as the plant grows (Lachenbruch et al., 2011). Comparing the two species mentioned above, Alchornea sidifolia and Anadenanthera colubrina, growing under the same environmental pressures, it is evident that the two species responded differently to wood radial variation pattern. Specifically, Anadenanthera peregrina, a species of the same genus as A. colubrina, was growing in another area and another climate type, but it still showed the same variation pattern for basic density and fiber dimensions, implicating the influence of ontogeny in this genus.

The complexity increases when we evaluate radial variation within the same species with trees that grew in the same area, but with different seed origins. For instance, in study with Gallesia integrifolia from three seed origins (Longui et al., 2011), it was found that wood radial variation depends on the origin of the seeds (genetic factor) more than the influence of climate and soil of studied area (environmental factors). 
Guimarães (2009) studied Anadenanthera colubrina at two locations with different types of vegetation and climate in Rio de Janeiro: Ilha Grande (Lowland Ombrophilous Dense Forest with Af climate type (tropical rainforest climate) according to Köppen (1948)) and Itatiaia (Montane Ombrophilous Dense Forest, Cwa climate type) and found variation in wood anatomy between the environments in almost all features also studied by us in the present study. In that study, vessel diameter and frequency did not vary significantly between the two environments, and the author did not evaluate hydraulic conductivity. Since Guimarães (2009) studied nondestructive samples close to the bark, we used values at $G$ position (close to bark) for comparison. Neither in the study of Guimarães nor in ours was the age of the trees determined, since tree samples were collected in the natural environment. However, since diameters of about $30 \mathrm{~cm}$ at breast height $(1.30 \mathrm{~m}$ in height $)$ described by Guimarães are close to ours, we estimate that trees had roughly similar ages. We present below the values obtained by Guimarães (2009) in each area: Ilha Grande: VEL $=348 \mu \mathrm{m}, \mathrm{VD}=126 \mu \mathrm{m}$, $\mathrm{VF}=13.5 \mathrm{n}^{\circ} \mathrm{mm}^{-2}, \mathrm{FL}=954 \mu \mathrm{m}, \mathrm{FWT}=5.7 \mu \mathrm{m}$, $\mathrm{RH}=188 \mu \mathrm{m}, \mathrm{RW}=43 \mu \mathrm{m}$ and $\mathrm{RF}=5 \mathrm{n}^{\circ} \mathrm{mm}^{-1}$; Itatiaia: $\mathrm{VEL}=310 \mu \mathrm{m}, \mathrm{VD}=145 \mu \mathrm{m}, \mathrm{VF}=19.5 \mathrm{n}^{\mathrm{o}} \mathrm{mm}^{-2}$, $\mathrm{FL}=1,095 \mu \mathrm{m}, \mathrm{FWT}=4.7 \mu \mathrm{m}, \mathrm{RH}=328 \mu \mathrm{m}$, $\mathrm{RW}=38 \mu \mathrm{m}$ and $\mathrm{RF}=5 \mathrm{n}^{\mathrm{o}} \mathrm{mm}^{-1}$. For comparison see our data in Table 1.

We know that radial growth, usually measured in $\mathrm{DBH}$, depends on several conditions, such as spacing, climate and soil types. Mattos and Seitz (2008) studied the formation of annual growth rings in Anadenanthera colubrina in the Pantanal, Mato Grosso State and estimated that the species takes at least 55 years to reach $40 \mathrm{~cm}$ in diameter. Obviously, it would be difficult to estimate the age of trees in the present study, as such estimate would depend on many factors.

According to Franco et al. (2007), the collection area of the present study is Montane Ombrophilous Dense Forest and the weather, according to CEPAGRI (2014), is Cwa (humid subtropical climate) for Embu municipality. These are the same characteristics as those of Itatiaia, according to Morim (2002), Oliveira (2001) and
SIMERJ (Sistema de Meteorologia do Estado do Rio de Janeiro), INMET (Instituto Nacional de Metereologia), as reported by Guimarães (2009). Except for vessel element length, which was longer in our study when compared to the results of Guimarães (2009), the values of vessel diameter, fiber length, fiber wall thickness, and ray height were similar between the present study and those of Itatiaia by Guimarães (2009), while our values of vessel frequency and ray width were closer to those found in Ilha Grande by Guimarães (2009) (see Table 1). Based on this comparison, we asked if the largest number of similarities between Embu and Itatiaia could be attributed to the occurrence of the same vegetation and climate types. Once again, the relative contribution of environmental $v s$. genetic factors becomes relevant. The fact is that $A$. colubrina presents a clear radial variation in wood structure in different vegetation types, e.g., increase in vessel diameter and fiber lenght.

Plourde et al. (2014) investigated tropical trees in northeastern Costa Rica and they found radial changes in wood specific gravity in 42 of 74 species, with 37 species exhibiting increases from pith to bark, and 5 exhibiting decreases. We also found increase in wood density from pith to bark in A. colubrina, based on the Plourde's study, our result appears in most tropical species. Wiemann and Williamson $(1988 ; 1989)$ proposed that increasing density in the radial direction are related to increasing mechanical requirements when tree grows in thickness and may be linked to successional group, since pioneer species grow rapidly in the early years (lighter wood) to achieve necessary height to obtain light, and then there is an mechanical reinforcement with increase in density. Noting that A. colubrina is pioneer species (Lorenzi, 2002).

\section{CONCLUSIONS}

The results suggest that Anadenanthera colubrina has a very common radial variation pattern from pith-to-bark with an increase in vessel diameter, favoring hydraulic conductivity, fiber wall thickness and length, ray height and width, and basic density. 
Although the negative relationship between vessel diameter and frequency is well reported for many species, it has not been observed in A. colubrina because vessel frequency oscillates radially. Our tree samples were collected in the natural environment, specifically Montane Ombrophilous Dense Forest; however, this typical radial pattern also occurs in other native species in planting conditions, obviously with some changes depending on species.

\section{ACKNOWLEDGMENTS}

The authors thank Sonia Godoy Campião for laboratory assistance.

\section{REFERENCES}

ALBUQUERQUE, U.P.; ANDRADE, L.H.C. Conhecimento botânico tradicional e conservação em uma área de caatinga no Estado de Pernambuco, Nordeste do Brasil. Acta Botanica Brasilica, v. 16, n. 3, p. 273-285, 2002a.

Uso de recursos vegetais da Caatinga: o caso do agreste do Estado de Pernambuco (Nordeste do Brasil). Interciência, n. 7, p. 336-345, 2002 b.

BERLYN, G.P.; MIKSCHE, J.P. Botanical microtechnique and cytochemistry. Ames: The Iowa University Press, 1976. 326 p.

BOSMAN, M.T.M. et al. Radial variation in wood properties of naturally and plantation grown light red meranti (Shorea sp., Dipterocarpaceae). IAWA Journal, v. 15, n. 2, p. 111-120, 1994.

CARVALHO, P.E.R. Espécies florestais brasileiras: recomendações silviculturais, potencialidade e uso da madeira. Brasília, DF: EMBRAPA-CNPF, 1994. $640 \mathrm{p}$.

CENTRO DE PESQUISAS METEOROLÓGICAS E CLIMÁTICAS APLICADAS À AGRICULTURA CEPAGRI. Clima dos municípios paulistas. Available at: <http://www.cpa.unicamp.br/outrasinformacoes/clima-dos-municipios-paulistas. html>. Access on: 8 Mar. 2014.

FAN, X.; CAO, K.F.; BECKER, P. Axial and radial variations in xylem anatomy of angiosperm and conifer trees in Yunnan, China. IAWA Journal, v. 30, n. 1, p. 1-13, 2009.
FRANCO, G.A.D.C. et al. Importância dos remanescentes florestais de Embu - SP para a conservação da flora regional. Biota Neotropica, v. 7, n. 3, p. 145-161, 2007.

GLASS, S.; ZELINKA, S.L. Moisture relations and physical properties of wood. In: ROSS, R. (Ed.). Wood handbook - wood as an engineering material. $100^{\text {th }}$ ed. Madison: U.S. Department of Agriculture, Forest Service, Forest Products Laboratory, 2010. p. 4-1-4-19. (General Technical Report FPL-GTR-190).

GUIMARÃES, R.C. Anatomia do lenho de Anadenanthera colubrina em diferentes fitofisionomias da Floresta Atlântica no Estado do Rio de Janeiro: Ilha Grande e Itatiaia - Rio de Janeiro. 2009. 44 f. Dissertação (Mestrado em Botânica) - Instituto de Pesquisas Jardim Botânico do Rio de Janeiro/Escola Nacional de Botânica Tropical, Rio de Janeiro.

IAWA COMMITTEE. IAWA list of microscopic features for hardwood identification. IAWA Bulletin, v. 3, n. 10, p. 219-332, 1989.

JOHNSON, D.V. Relatório sobre o manejo da caatinga, semi-árido do Nordeste Brasileiro. In: PROJETO PNUD/FAO/BRA/85/007. Natal, 1985. (Circular Técnica, 3).

LACHENBRUCH, B.; MOORE, J.R.; EVANS, R. Radial variation in wood structure and function in woody plants, and hypotheses for its occurrence. In: MEINZER, F.C.; LACHENBRUCH, B.; DAWSON, T.E. (Ed.). Size- and age-related changes in tree structure and function. Dordrecht: Springer, 2011. p. 121-164.

LIMA, I.L. et al. Variação radial da densidade básica e dimensões celulares de Croton floribundus. Floresta, v. 40, n. 3, p. 663-670, 2010.

et al. Densidade básica e dimensões celulares da madeira de Balfourodendron riedelianum em função da procedência e posição radial. Revista do Instituto Florestal, v. 23, n.2, p. 217-230, 2011a.

. et al. Variação radial da densidade básica e dimensões celulares da madeira de Cariniana legalis (Mart.) O. Kuntze em função da procedência. Cerne, v. 17, n. 4, p. 517-524, 2011 b. 
LONGUI, E.L. et al. Variação anatômica radial do lenho de açoita-cavalo (Luehea divaricata) e sua influência na densidade aparente. Revista do Instituto Florestal, v. 21, n. 2, p. 181-190, 2009.

et al. Variação radial das características anatômicas, densidade aparente, teores de extrativos, lignina e holocelulose na madeira de Piptadenia gonoacantha (Mart.) Macbr. Scientia Forestalis, v. 38, n. 3, p. 341-353, 2010.

. et al. Seed provenance influences the wood structure of Gallesia integrifolia. IAWA Journal, v. 32, n. 3, p. 361-374, 2011.

. et al. Estrutura do lenho de Plathymenia reticulata e algumas implicações na eficiência hidráulica e resistência mecânica. Floresta, v. 42, n. 2, p. 335-346, 2012.

LORENZI, H. Árvores brasileiras: manual de identificação e cultivos de plantas arbóreas do Brasil. 2. ed. São Paulo: Nova Odessa, 2002. 382 p.

MATTOS, P.P.; SEITZ, R.A. Growth dynamics of Anadenanthera colubrina var. cebil and Tabebuia impetiginosa from Pantanal Mato-Grossense, Brazil. Ciência Florestal, v. 18, n. 4, p. 427-434, 2008.

MONTEIRO, J.M. et al. Use and traditional management of Anadenanthera colubrina (Vell.) Brenan in the semi-arid region of northeastern Brazil. Journal of Ethnobiology and Ethnomedicine, v. 2, p. 1-18, 2006.

MORIM, M.P. Leguminosae arbustivas e arbóreas do Parque Nacional do Itatiaia: abordagem florístico-taxonômica. 2002. 215 p. Tese (Doutorado em Ciências Biológicas - Botânica) - Universidade Federal do Rio de Janeiro, Rio de Janeiro.

. Anadenanthera. In: LISTA de espécies da flora do brasil. Jardim Botânico do Rio de Janeiro. Available at: $<\mathrm{http}$ ://floradobrasil.jbrj.gov.br/jabot/ floradobrasil/FB18071>. Access on: 26 Mar. 2014.

OLIVEIRA, R.R. Ação antrópica e resultantes sobre a estrutura e composição da Mata Atlântica na Ilha Grande, RJ. Rodriguésia, v. 53, n. 82, p. 33-58, 2001.

PETERS, C.M. Economic botany and management potential of neotropical seasonally dry forests. In: DIRZO, R. et al. (Ed.). Seasonally dry tropical forests: ecology and conservation. Washington, D. C.: Island Press, 2011. p. 239-258.
PLOURDE, B.T.; BOUKILI, V.K.; CHAZDON, R.L. Radial changes in wood specific gravity of tropical trees: inter- and intraspecific variation during secondary succession. Functional Ecology, 2014. doi: 10.1111/1365-2435.12305.

SANTINI JUNIOR, L. et al. Análise anatômica qualitativa e quantitativa e densidade básica da madeira de Alchornea sidifolia Müll. Arg. (Euphorbiaceae). Revista do Instituto Florestal, v. 22, n. 2, p. 201-214, 2010.

SANTOS, C.M. et al. A densidade básica e características anatômicas variam radialmente na madeira de Astronium graveolens Jacq. (Anacardiaceae). Revista do Instituto Florestal, v. 23, n. 2, p. 191-201, 2011.

SCHOLZ, A. et al. How to quantify conduits in wood? Frontiers in Plant Science, v. 4, p. 1-11, 2013.

TEIXEIRA, B.M.R. Variabilidade radial e longitudinal de propriedades da madeira de angico-vermelho (Anadenanthera peregrina (L.) Speg. 2008. 52 f. Dissertação (Mestrado em Ciência Florestal) - Universidade Federal de Viçosa, Viçosa.

WIEMANN, M.C.; WILLIAMSON, G.B. Extreme radial changes in wood specific gravity in some tropical pioneers. Wood and Fiber Science, v. 20, p. 344-349, 1988.

Radial gradients in the specific gravity of wood in some tropical and temperate trees. Forest Science, v. 35, p. 197-210, 1989. 